\title{
Prevalence of rotavirus, adenovirus, hepatitis A virus and enterovirus in water samples collected from different region of Peshawar, Pakistan
}

\author{
Tahir Ahmad ${ }^{* 1,2}$, Najma Arshad ${ }^{*}$, Fazal Adnan², Najam-us-Sahar Sadaf Zaidi², \\ Muhammad Talha Shahid ${ }^{2}$, Usman Zahoor ${ }^{3}$, Muhammad Sohail Afzal ${ }^{4}$, Sadia Anjum ${ }^{5}$ \\ ${ }^{1}$ Department of Zoology, University of the Punjab, Lahore, Pakistan \\ ${ }^{2}$ National University of Sciences and Technology, Islamabad, Pakistan \\ ${ }^{3}$ Comsat Institute of Information Technology, Abbottabad, Pakistan \\ ${ }^{4}$ Department of Chemistry, School of Sciences, University of Management and Technology (UMT), Lahore, Pakistan \\ ${ }^{5}$ University of Hail, Saudi Arabia
}

Ahmad T, Arshad N, Adnan F, Zaidi NS, Shahid MT, Zahoor U, Afzal MS, Anjum S. Prevalence of rotavirus, adenovirus, hepatitis A virus and enterovirus in water samples collected from different region of Peshawar, Pakistan. Ann Agric Environ Med. 2016; 23(4): 576-580. doi: $10.5604 / 12321966.1226849$

\begin{abstract}
Viral gastroenteritis and other water-borne diseases are the most neglected areas of research in Pakistan. To determine the quality of water, 4 enteric viruses were studied from different localities of Peshawar, Pakistan. The study validates the viral detection method for Rotavirus (RV), Human adenovirus (HAdV), Enterovirus (EV) and Hepatitis A virus (HAV), directly from water sources of rural areas of Peshawar, KPK, Pakistan. Overall, 95 five water samples were tested; among them, 9.47\% were positive for RV, 38.94\% for HAdV, 48.42\% for EV and $12.63 \%$ for HAV. The presence of these viruses in water was directly correlated with meteorological data. High prevalence of EV and HAdV was detected frequently in the wet season from May - September, which can be the potential cause of spreading of gastroenteritis in the population. Environmental surveillance is an additional tool to evaluate the epidemiology of enteric viruses circulating in a given community.
\end{abstract}

\section{Key words}

water, enteric viruses, molecular epidemiology, diagnostic, public health

\section{INTRODUCTION}

Pathogenic microorganisms greatly affect the quality of both surface and subsurface water. Enteric pathogens are mostly derived from faecal contamination. Presently, the water quality is monitored evaluating the presence or absence of coliforms [1]. There are different human viruses which replicate in the gastrointestinal tract and are shed into the surrounding water by the faecal -oral route. These agents are collectively named enteric viruses.

Most of these viruses are highly resistant with a nonenveloped structure which can live and survive for many months in diverse environments [2]. The most common type of enterovirus are rotavirus, adenovirus, norovirus, and hepatitis A [3]. Non-enveloped viruses are more resistant to decontamination processes and hence are better candidates than coliforms for tracking the source of contamination in the drinking and waste water treatment process [4].

Enterovirus belongs to the genus picornaviridae family, most of these viruses remain asymptomatic infections in humans, but some may be responsible for various complications, such as meningitis, acute flaccid paralysis, respiratory illness, myocarditis and other clinical outcomes [5]. Adenoviruses are double-standard DNA viruses; they are members of the adenoviridae family and are the most stable virus in the environment. Adenovirus show a higher degree of resistance to UV light when compared to other enteroviruses. It causes not only gastroenteritis but is also associated with conjunctivitis, cystitis and respiratory infections in humans [6].

Address for correspondence: Najma Arshad* and Tahir Ahmad* , Associate Professor, Department of Zoology, University of the Punjab, Lahore

Email: najmaarshad@yahoo.com; baig42@gmail.com

Received: 26 June 2015; accepted: 23 October 2015
Rotavirus is a member of the family of Reoviridae and is a double-stranded RNA virus. It causes server diarrhea among infants and young children. Nearly all children at the age of 5 have been affected by rotaviral infection. In addition to its impact on human health, rotavirus can also infect livestock. There are 5 serological species (A-E) among them: groups A, $B$ and $C$ are associated with infection in humans and a variety of animals [7]. Rota $\mathrm{A}$ is the most widespread cause of acute gastroenteritis that requires medical attention for young children, and is held responsible for more than half a million deaths among young children under 5 years of age per annum worldwide [8]. Like other enterovirus, the Hepatitis A virus (HAV) is primarily transmitted through the faecal oral route, and have been reported and associated with contaminated water supplies in both urban and rural areas of Pakistan [9].

Peshawar has evolved predominantly into one of Pakistan's most ethnically and linguistically diverse cities, and in the last 3 decades there has been a significant increase in the urban population, in part due to internal migration of people in search of better employment opportunities, education, and services, and in part because of the influx of Afghan refugees and other people internally displaced due to military operations and civil unrest in neighbouring regions. In this study, water samples were collected from different region of Peshawar, and tested by Polymerase chain reaction (PCR) technique for the qualitative analysis of enterovirus, rotavirus, Hepatitis A virus and Adenovirus. Consensus primers were designed for the efficient detection of these viruses from the environment.

This is the first study detecting the contamination of water by enteric virus from Peshawar. Peshawar's recorded history goes back as far as at least $539 \mathrm{BC}$, making it one of the oldest living cities in South Asia [10]. Since enteric infections are 
often reported in this city, the presented study was initiated to evaluate whether the old, leaky sewerage system or sewerage contamination is responsible for these events.

\section{MATERIALS AND METHODS}

Sampling sites and samples. Peshawar is the capital of Khyber Pakhtunkhwa (formerly called the North-West Frontier Province) and the administrative center and economic hub for the federally administered tribal area (FATA) of Pakistan. Peshawar is situated near the eastern end of the Khyber Pass, close to the Afghanistan border. This land is irrigated by various tributaries of the Pakhto and Bara rivers.

Water sample collection. The samples were collected during June 2014 - May 2015 from the surroundings of Peshawar. Ninety-five drinking and sewage water samples (1L) were collected from surface and subsurface water in sterilized plastic bottles. Physical parameter - $\mathrm{pH}$, temperature, BOD and COD - were measured directly from the source by multi-pH meter (Thermo Scientific, USA). Samples were transported immediately and stored in a laboratory at $4{ }^{\circ} \mathrm{C}$ until sample concentration.

Sample concentration. Samples were concentrated by using the adsorption elution method, as previously described by Katayama et al [11] with $0.45 \mu \mathrm{m}$ negatively charged membrane filters (HA, Millipore, USA). Prior to filtration, sewage samples were centrifuge at $4,000 \mathrm{rpm}$ for 5 minutes and then filtered through whatmann filter paper No. 10. $1 \mathrm{~L}$ of the water sample was mixed with $0.6 \mathrm{~g} \mathrm{MgCl}_{2}$ and $\mathrm{pH}$ adjusted to 5 with $10 \% \mathrm{HCl}$. Samples were passed through a Vacuum filtration assembly by using $0.45 \mu \mathrm{m}$ negatively charged membrane filters. Filtrates were discarded, the membranes rinsed with $100 \mathrm{ml}$ of $0.5 \mathrm{~mm} \mathrm{H}_{2} \mathrm{SO}_{4}(\mathrm{pH}: 3.0)$. $2.5 \mathrm{ml}$ of $1 \mathrm{mmNaOH}$ ( $\mathrm{pH}: 10.5$ ) was used for the elution of viral particle adsorbed by the membrane. Filtrate was then mixed with $12.5 \mu \mathrm{l}$ of $50 \mathrm{~mm} \mathrm{H}_{2} \mathrm{SO}_{4}$ and $12.5 \mu \mathrm{l}$ of $100 \mathrm{x}$ Tris-EDTA (TA) Buffer. The mixture was stored at $-80^{\circ} \mathrm{C}$ until processing.

Viral nucleic acid extraction. Viral RNA and DNA were extracted by using an RNA/DNA extraction kit (Invitrogen, USA) according to the given protocol. Viral RNA/DNA was kept at $-80^{\circ} \mathrm{C}$ until used.

PCR. The detection of Rotavirus, adenovirus, Hepatitis A virus and enterovirus from the water samples were amplified by using specific primers. The sequence of the primers and location and amplification band are shown in Table 1. PCR Thermal conditions were optimized and reactions standardized as follows:

(a) RV: cDNA: M.Mulv Buffer: $4 \mu \mathrm{l}, 10 \mathrm{mM}$ dNTPs: $2 \mu \mathrm{l}$, Rotavirus R- Primer: $1.5 \mu \mathrm{l}$, M.Mulv Enzyme: $0.6 \mu \mathrm{l}$, RNA Template: $8 \mu \mathrm{l}$, cDNA thermal conditions: $42^{\circ} \mathrm{C}$ for 1 hour, PCR recipe for Rotavirus: cDNA template: $6 \mu \mathrm{l}$, Dream Taq Buffer: $2.5 \mu \mathrm{l}, 2 \mathrm{mM}$ dNTPs: $2.5 \mu \mathrm{l}$. Forward Primer: $1.5 \mu \mathrm{l}$, Reverse Primer: $1.5 \mu$ l, Dream Taq Enzyme: $0.5 \mu \mathrm{l}$, NFWater: $5.5 \mu$ l. PCR carried by ABI thermal cycler (ABI, UK) under the following conditions; $94^{\circ} \mathrm{C}$ for $4 \mathrm{~min}$, 35cyles of $94^{\circ} \mathrm{C}$ for $1 \mathrm{~min}, 50^{\circ} \mathrm{C}$ for $1.5 \mathrm{~min}, 72^{\circ} \mathrm{C}$ for $1 \mathrm{~min}$, and extension at $72^{\circ} \mathrm{C}$ for $7 \mathrm{~min}$; (b) HAV: cDNA: M.Mulv Buffer: $4 \mu \mathrm{l}, 10$ mM dNTPs: $2 \mu \mathrm{l}$, HAV R- Primer: $1.5 \mu \mathrm{l}$, M.Mulv Enzyme: $0.6 \mu \mathrm{l}$, RNA Template: $5 \mu \mathrm{l}$, cDNA thermal conditions: $42^{\circ} \mathrm{C}$ for 1 hour. PCR carried by Esco thermocycler (ESCO, USA), PCR recipe was as follows: cDNA template: $5 \mu \mathrm{l}$, Dream Taq Buffer: $2.5 \mu \mathrm{l}, 2 \mathrm{mM}$ dNTPs: $1.5 \mu \mathrm{l}$. Forward Primer: $1.5 \mu \mathrm{l}$, Reverse Primer: $1.5 \mu \mathrm{l}$, Dream Taq Enzyme: $0.5 \mu \mathrm{l}$, NFWater: $7.5 \mu$ l. Total volume: $20 \mu \mathrm{l}$. PCR conditions were as follows: first round of amplification: $94^{\circ} \mathrm{C}$ for $3 \mathrm{~min}$ followed by $35 \mathrm{cyle}$ at $94^{\circ} \mathrm{C}$ for $1 \mathrm{~min}, 55^{\circ} \mathrm{C}$ for $1 \mathrm{~min}, 72^{\circ} \mathrm{C}$ for $45 \mathrm{sec}$ and extension $72^{\circ} \mathrm{C}$ for $7 \mathrm{~min}$. Second round of Amplification: $94^{\circ} \mathrm{C}$ for $3 \mathrm{~min}, 35$ cycles at $94^{\circ} \mathrm{C}$ for $45 \mathrm{sec}, 52^{\circ} \mathrm{C}$ for $45 \mathrm{sec}, 72^{\circ} \mathrm{C}$ for $1 \mathrm{~min}$ and extension for $72^{\circ} \mathrm{C}$ for $7 \mathrm{~min}$.

(c) HAdV: PCR mixture of adenovirus consists of the following recipe: $\mathrm{MgCl}_{2}: 2.5 \mu \mathrm{l}$, Taq Buffer: $2.5 \mu \mathrm{l}, 2 \mathrm{mM}$ dNTPs: $2 \mu$ l. Primer Forward: $1 \mu \mathrm{l}$, Primer Reverse: $1 \mu \mathrm{l}$, NF- Water: $10.5 \mu \mathrm{l}$, Tap Polymerase: $0.5 \mu \mathrm{l}$. Total volume: $20 \mu \mathrm{l}$. PCR were carried by ABI thermal cycler (ABI, UK) under the following conditions: $95^{\circ} \mathrm{C}$ for $3 \mathrm{~min}, 35$ cycles at $94^{\circ} \mathrm{C}$ for $30 \mathrm{sec}, 54^{\circ} \mathrm{C}$ for $30 \mathrm{sec}, 35 \mathrm{cycles}$ at $72^{\circ} \mathrm{C}$ for $1 \mathrm{~min}$. Extension at $72^{\circ} \mathrm{C}$ for $7 \mathrm{~min}$.

(d) EnV: The recipe for Enteroviurs cDNA was as follows: M.Mulv Buffer: $4 \mu$ l, 10 mM dNTPs: $2 \mu$ l, RNase Inhibitor: $0.2 \mu$ l. Reverse Primer: $1.5 \mu$ l, RT- Enzyme: $0.6 \mu \mathrm{l}$, RNA Template: $10 \mu$ l. Thermal condition: $42^{\circ} \mathrm{C}$ for 1 hour. PCR were carried out in ESCO Thermocycler (Esco, USA), PCR recipe as follows: cDNA Template: 5-8 $\mu \mathrm{l}, 0.2 \mathrm{mM}$ dNTPs: $2 \mu \mathrm{l}, 2.5 \mathrm{mM} \mathrm{MgCl}_{2}: 2 \mu \mathrm{l}$, PCR buffer: $2 \mu \mathrm{l}$, 2 pmole F-Primer: $2 \mu \mathrm{l}, 2$ pmole R-Primer: $2 \mu \mathrm{l}$. DNA Taq polymerases: $0.5 \mu \mathrm{l}, \mathrm{N} / \mathrm{F}$ water: volume up to $20 \mu \mathrm{l}$. PCR thermal cycling conditions performed by using Esco thermal cycler (Esco, USA), conditions as follows: $95^{\circ} \mathrm{C}$ for $3 \mathrm{~min}, 35 \mathrm{cycles}$ at $95^{\circ} \mathrm{C}$ for $30 \mathrm{sec}, 58^{\circ} \mathrm{C}$ for $30 \mathrm{sec}, 35 \mathrm{cycle}$ $72^{\circ} \mathrm{C}$ for $1 \mathrm{~min}$. Extension at $72^{\circ} \mathrm{C}$ for $7 \mathrm{~min}$.

Gel electrophoresis. PCR results were analyzed in 2\% $1 \mathrm{X}$ TAE agarose gel containing $2 \mathrm{ul}$ of $10 \mathrm{mg} / \mathrm{ml}$ ethidium bromide. 5-8 $\mu \mathrm{l}$ sample were mixed with $5 \mathrm{ul}$ loading dye (Fermentas) and were loaded in the agarose gel along with reference ladder (Fermentas) which is submerged in $1 \mathrm{X}$ TAE buffer pH7.0. Gels were electrophoresed for 25 to 35 minutes at 90 Volts. The bands were visualized by gel documentation system (Dolphin Whealtec, USA).

Table 1. Primer and conditions used for amplification of Rotavirus (RV), Human adenovirus (HAdV), Enterovirus (EV) and Hepatits A virus (HAV) in PCR

\begin{tabular}{lllll}
\hline Viruses & $\begin{array}{l}\text { Primer } \\
\text { name }\end{array}$ & Sequence & $\begin{array}{l}\text { Nucleotide } \\
\text { position }\end{array}$ & $\begin{array}{l}\text { Product } \\
\text { size }\end{array}$ \\
\hline RV & RT-F & GTTGTTGTCATGCTGCCAT & $169-187$ & $322 \mathrm{bp}$ \\
\hline RAdV & Ad-1F & AGTACAGTACCAAATTCAT & $471-490$ & \\
\hline & Ad-2F* & TCATATCATGGGTAACAGACAT & $33000-33021$ & $202 \mathrm{bp}$ \\
\hline & Ad-2R* & CCCATGTAGGCGTGGACTTC & $33182-33201$ & \\
\hline EV & En-1F & CAAGCACTTCTGTTCCCCGG & $164-184$ & $362 \mathrm{bp}$ \\
\hline & En-1R & ATTGTCACCATAAGCAGCCA & $599-580$ & \\
\hline & En-2R* & CTTGCGCGTTACGAC & $562-512$ & \\
\hline HAV & HAVFP & GTTTTGCTCCTCTTTATCATGCTATG & $2109-2135$ & $246 \mathrm{bp}$ \\
\hline & HAVRP & GGAAATGTCTCAGGTACTTCTTT & $2330-2355$ & \\
\hline
\end{tabular}




\section{RESULTS}

Ninety-five Water samples were taken from different sites of Peshawar from June 2014 - May 2015. All samples were analyzed by conventional PCR for the prevalence of Rota virus, Human Adenovirus, Hepatitis A virus and Enterovirus. Of these samples, Rotavirus was found only in 9 samples with $9.47 \%$, prevalence while 37 samples showed HAdV genome (38.94\%), whereas only 12 samples showed HAV positive results (12.63\%). Among all viruses detected in water, Enterovirus was highly prevalent - found in $48.42 \%$ of the water samples (Tab. 2).

Table 2. Detection of rotavirus (RV), Human Adenovirus (HAdV), Hepatitis $A$ virus (HAV) and Enterovirus (EV) genome in water samples collected from Peshawar (KPK), Pakistan. Nos. indicate sampling sites (Fig. 1): + indicates viral detection; - indicate absence of viral detection

\begin{tabular}{lcccc}
\hline $\begin{array}{l}\text { Sampling } \\
\text { site }\end{array}$ & Rotavirus (RV) & $\begin{array}{c}\text { Human Adeno } \\
\text { Virus (HAdV) }\end{array}$ & $\begin{array}{c}\text { Enterovirus } \\
(\text { EV) }\end{array}$ & $\begin{array}{c}\text { Hepatitis A } \\
\text { virus (HAV) }\end{array}$ \\
\hline 1 & + & + & + & - \\
\hline 2 & - & - & - & - \\
\hline 8 & - & + & + & + \\
\hline 10 & - & + & + & - \\
\hline 13 & + & - & - & + \\
\hline 14 & - & + & + & - \\
\hline 17 & - & - & + & + \\
\hline 19 & - & - & + & - \\
\hline
\end{tabular}

Most of the positive samples were obtained during the months May - September. June was the month with the highest viral detection rate, while lowest viral detection rate was recognized in December - March (winter season). Almost all sampling points showed the presence of at least one group of viruses, but Adenovirus and Enterovirus showed the highest viral detection rate. Figure 1 indicates the sampling sites; 14 samples were obtained randomly from different location of Peshawar, samples collected from locations 1 and 3 were obtained from sewage water which receives waste water from all the major channels of the city, and showed the highest viral detection for all the viruses studied.

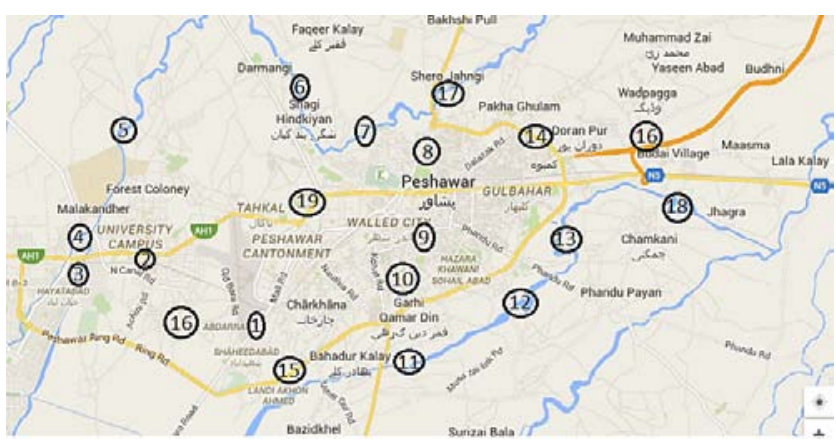

Figure 1. Map showing sampling sites in Peshawar City, Pakistan

Specific primers were designed to amplify the target sequence of the given viruses (Fig. 3). Gel electrophoresis clearly showed the result of Rotavirus, Adenovirus and Hepatitis A virus with 322bp, 202bp, 246bp amplifications, respectively. Enterovirus with $362 \mathrm{bp}$ amplification were found from both drinking and sewage water samples (Figs. 4, 5).

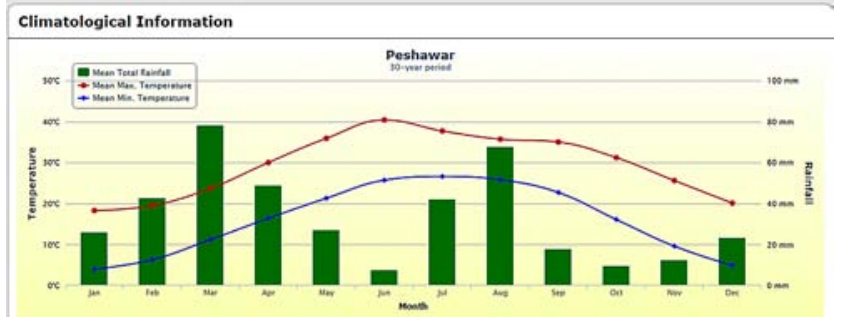

Figure 2. Climatological information of Peshawar KPK, Pakistan, showing average temperature $\left({ }^{\circ} \mathrm{C}\right)$ with rainfall pattern $(\mathrm{mm})$. Source: adapted from the Pakistan Meteorological Office (25)

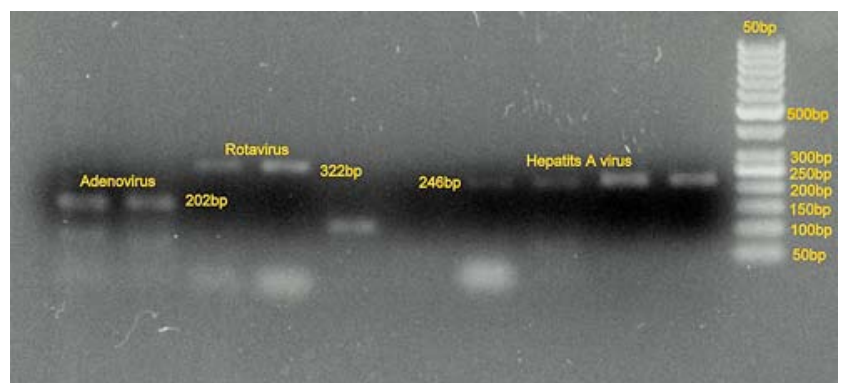

Figure 3. 1.5\% Agarose Gel electrophoresis showing 50bp molecular marker with amplified product of Adenovirus, Rotavirus and Hepatitis A virus with 202bp, 322bp and $246 \mathrm{bp}$, respectively

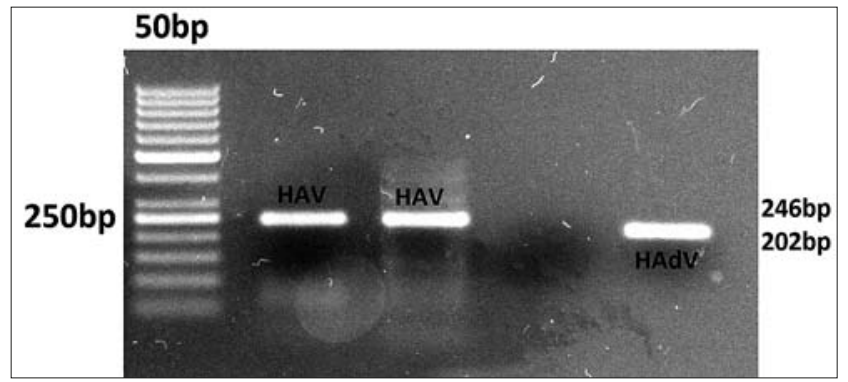

Figure 4. Ethidium bromide stained $1.5 \%$ agarose gel electrophoresis showing the amplified product of HAV and HAdV.

Lane $\mathrm{M}$ - 50bp molecular marker;

Lanes1 and 2 - 246bp amplified product of HAV;

Lane 4 - 202bp amplified product of HAdV

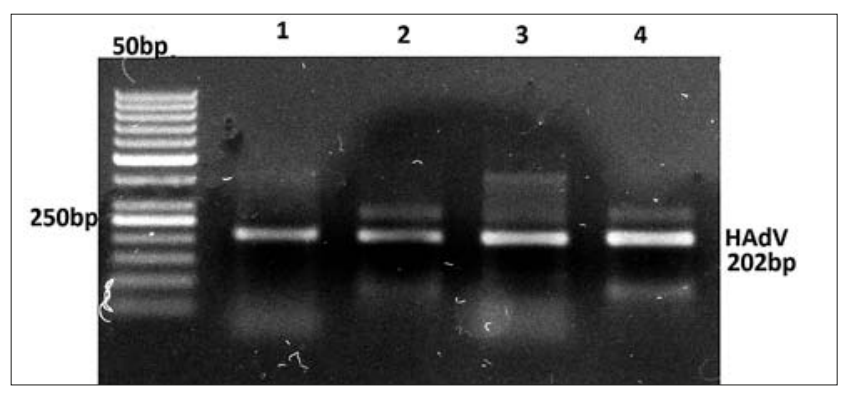

Figure 5. Ethidium bromide stained $1.5 \%$ agarose gel electrophoresis showing the amplified product of HAdV.

Lane $\mathrm{M}-50 \mathrm{bp}$ molecular marker;

Lanes 1 - 4- nested PCR result for HAdV with 202bp amplified product.

\section{DISCUSSION}

Peshawar is the largest and oldest city of Khyber Pakhtunkhwa (KPK) province, with 7 tribal agencies located around the city. The total population is about 357,5000 inhabitants. The old drainage system known as Shahi Khata built under the rule of Maharaja Ranjit Singh, last repaired in 1890 during 
British reign, is still intact in a debilitated state [8]. The population has substantially increased and the drainage system is no longer able to carry all the sewage water from the inner part of the city. These drainage system is filled with dirt in pipelines with little or no maintenance, and is unable to accommodate all the water, especially during heavy rain. The Budhni stream usually overflows in the rainy season, resulting in filthy water flowing onto the streets outside homes, and the whole area turns into a huge, dirty puddle which can be the potential cause of viral gastroenteritis. The waste water receives untreated sewage from at least one-third of the population of the city. In the current study, the faecal contamination in surface and subsurface water was evaluated by the detection of Rotavirus, Human adenoviruses, Hepatitis A and Enteroviruses.

The most prevalent group of viruses, such as Enteroviruses and Human adenoviruses, were detected during May September (Tab. 2). There could be a relationship with the prevalence of different viruses with respect to meteorological data, such as minimum and maximum temperature, monthly precipitation, and annual rainfall pattern (Fig. 2). Other parameters - air humidity, wind speed, wind direction, water temperature and turbidity - may also be associated with the viral detection pattern in the given areas [12].

Most stable viruses which can sustain in diverse kind of environments are Adenoviruses and Enteroviruses. The Adenovirus genome is composed of double-stranded DNA and is therefore more resistant and stable to adverse conditions (UV irradiation), as confirmed by its presence in $38.94 \%$ of water samples in the presented study. A recent study of environmental samples from 3 lakes in Wuhan, Hubei Province, China, have shown similar findings with Enterovirus being the most commonly detected virus, followed by Norovirus genogroup I [13]. Previously, Fong et al., (2005) evaluated the presence of Enterovirus, Adenoviruses, and Bovine Enterovirus (BEV) in water samples obtained from Georgia [14]. The authors detected Enterovirus in $48.42 \%$ of water samples, while only $9.47 \%$ of samples were positive for Rotavirus. Similar results were also obtained from Seoul, Korea where 33.3\% enterovirus samples were positive from Han River, Seoul, South Korea $[15,16]$.

Pakistan is a developing country with a high population density which experiences myriad human health effects because of climate change. Most of the enteric associated diseases are directly or indirectly concerned with the water, especially in urban areas of the KPK of Pakistan. The presented study describes a pilot study to investigate the presence of different enteric viruses in stream water and the sewage environment of urban areas of Peshawar. Molecularbased assay, such as RT-PCR, were applied for the detection of enteric viruses from water [17].

The high prevalence of EV (48.42\%) and HAdV (38.94\%) indicates serious sewerage contamination in the city of Peshawar. HAV was detected in $12.63 \%$ of water samples which was higher than rotavirus (9.47\%). Detection of these viruses even in low quantity pose a serious threat to the general population, especially children under the age of 10 years $[18,19]$. Poor water and sewage systems are considered to be the main reasons for Hepatitis $\mathrm{A}$ and $\mathrm{E}$ infection endemic in Pakistan [20]. The results of the current study are in line with previous reports indicating high pervasiveness of diarrheal viruses in the developing countries of Asia, such as Pakistan, Bangladesh, India, Nepal, Vietnam, and even in
China [21]. Poor distribution of water and the open drainage system in Peshawar; especially during the raining season when an overflow of drainage water can contaminate not only the drinking water pipeline, but also viruses accumulate on the ground water resources [22] and are cause for great alarm. In flood-affected communities such as Pakistan the leading causes of illness are skin infections, acute watery diarrhoea and acute respiratory infections. The 2010 flood resulted in 115,922 cases of acute diarrhoea reported in fixed and outreach medical centres before the 12 August. In Khyber Pakhtunkhwa, the worst affected province, acute diarrhoea was recorded as the foremost cause of illness, accounting for $17 \%$ of the medical consultations [23].

The rates of detection of HAdV and EV in the presented study are higher than those found on urban areas of central Punjab of Pakistan. Indeed, HAdV and other enteroviruses are often found to be highly prevalent in environmental water. Prevalence of these viruses in this study is directly correlated with meteorological data which indicate that maximum temperature and rainfall appear in July and August (Fig. 2). Rainfall patterns reduce the fresh water supply as most of the surface water becomes contaminated with sewage water, which definitely increases the risk factor for the general population [24].

Enteric viruses represents a significant risk to public health. Although the RT-PCR method is not used directly for viral infectivity, the presented results show that the water obtained from the urban city of KPK, Pakistan, was heavily contaminated with $\mathrm{HAdV}$ and $\mathrm{EV}$, and to a lesser extent with $\mathrm{RV}$ and HAV. The prevalence of these viruses in the water is therefore a potential health risk for the rural communities directly or indirectly exposed to these water sources. Finally, this study demonstrates that environmental surveillance is an effective tool for studying the prevalence of enteric viruses in water systems. The improvement of drinking water quality and adequate sanitation is proposed in order to help reduce the burden of enteric diseases in Peshawar and other densely populated areas of Pakistan, and in other developing countries.

\section{Acknowledgments}

The authors are grateful to the National University of Sciences and Technology for funding the study and providing laboratory facilities for completion of the research project.

\section{REFERENCES}

1. Odonkor ST, Ampofo JK. Escherichia coli as an indicator of bacteriological quality of water: an overview. Microbiol Res. 2013; 4(1): e2.

2. Pellegrinelli L, Binda S, Chiaramonte I, Primache V, Fiore L, Battistone A, et al. Detection and distribution of culturable Human Enteroviruses through environmental surveillance in Milan, Italy. J Appl Microbiol. 2013; 115(5): 1231-9.

3. Fong T-T, Lipp EK. Enteric viruses of humans and animals in aquatic environments: health risks, detection, and potential water quality assessment tools. Microbiol Mol Biol Rev. 2005; 69(2): 357-71.

4. Noble R, Allen S, Blackwood A, Chu W, Jiang S, Lovelace G, et al. Use of viral pathogens and indicators to differentiate between human and non-human fecal contamination in a microbial source tracking comparison study. J Water Health. 2003; 1: 195-207.

5. Palacios G, Oberste M. Enteroviruses as agents of emerging infectious diseases. J Neurovirol. 2005; 11(5): 424-33.

6. Gray GC, McCarthy T, Lebeck MG, Schnurr DP, Russell KL, Kajon $\mathrm{AE}$, et al. Genotype prevalence and risk factors for severe clinical 
adenovirus infection, United States 2004-2006. Clin Infect Dis. 2007; 45(9): 1120-31.

7. Grimwood K, Lambert SB. Rotavirus vaccines: opportunities and challenges. Hum Vaccin. 2009; 5(2): 57-69.

8. Ahmad R. Hacking away: Shahi Khata undergoes another debilitating cleaning exercise. The Express Tribune. 2013.

9. Khan FJ, Javed Y. Delivering access to safe drinking water and adequate sanitation in Pakistan: Pakistan Instiute of Development Economics; 2007.

10. Dani AH. Peshawar: Historic city of the Frontier: Sang-E-Meel Publication; 1995.

11. Katayama H, Shimasaki A, Ohgaki S. Development of a virus concentration method and its application to detection of enterovirus and Norwalk virus from coastal seawater. Appl Environ Microbiol. 2002; 68(3): 1033-9.

12. Wong M, Kumar L, Jenkins TM, Xagoraraki I, Phanikumar MS, Rose JB. Evaluation of public health risks at recreational beaches in Lake Michigan via detection of enteric viruses and a human-specific bacteriological marker. Water Res. 2009; 43(4): 1137-49.

13. Allmann E, Pan L, Li L, Li D, Wang S, Lu Y. Presence of enteroviruses in recreational water in Wuhan, China. J Virol Methods. 2013; 193(2): $327-31$.

14. Fong T-T, Griffin DW, Lipp EK. Molecular assays for targeting human and bovine enteric viruses in coastal waters and their application for library-independent source tracking. Appl Environ Microbiol. 2005; 71(4): 2070-8.

15. Lee SH, Lee C, Lee K, Cho H, Kim SJ. The simultaneous detection of both enteroviruses and adenoviruses in environmental water samples including tap water with an integrated cell culture-multiplex-nested PCR procedure. J Appl Microbiol. 2005; 98(5): 1020-9.

16. Chapron CD, Ballester NA, Fontaine JH, Frades CN, Margolin AB. Detection of astroviruses, enteroviruses, and adenovirus types 40 and 41 in surface waters collected and evaluated by the information collection rule and an integrated cell culture-nested PCR procedure. Appl Environ Microbiol. 2000; 66(6): 2520-5.

17. Kiulia N, Netshikweta R, Page N, Van Zyl W, Kiraithe M, Nyachieo $A$, et al. The detection of enteric viruses in selected urban and rural river water and sewage in Kenya, with special reference to rotaviruses. J Appl Microbiol. 2010; 109(3): 818-28.

18. Curns AT, Steiner CA, Barrett M, Hunter K, Wilson E, Parashar UD, Reduction in acute gastroenteritis hospitalizations among US children after introduction of rotavirus vaccine: analysis of hospital discharge data from 18 US states. J Infect Dis. 2010; 201(11): 1617-24.

19. Ahmed M, Munshi S, Nessa A, Ullah M, Tabassum S, Islam M. High prevalence of hepatitis A virus antibody among Bangladeshi children and young adults warrants pre-immunization screening of antibody in HAV vaccination strategy. Indian J Med Microbiol. 2009; 27(1): 48.

20. Control CfD, Prevention. Establishment of a viral hepatitis surveillance system--Pakistan, 2009-2011. MMWR Morbidity and mortality weekly report. 2011; 60(40): 1385 .

21. Hakim ST, Afaque F, Javed S, Kazmi SU, Nadeem SG. Microbial agents responsible for diarrheal infections in flood victims: a study from Karachi, Pakistan. Open J Med Microbiol. 2014; 2014.

22. Pujari PR, Padmakar C, Labhasetwar PK, Mahore P, Ganguly A. Assessment of the impact of on-site sanitation systems on groundwater pollution in two diverse geological settings-a case study from India. Environ Monit Assess. 2012; 184(1): 251-63.

23. Baqir M, Sobani ZA, Bhamani A, Bham NS, Abid S, Farook J, et al. Infectious diseases in the aftermath of monsoon flooding in Pakistan. Asian Pac J Trop Biomed. 2012; 2(1): 76-9.

24. Dhara VR, Schramm PJ, Luber G. Climate change \& infectious diseases in India: Implications for health care providers. Indian J Med Res. 2013; 138(6): 847.

25. Salma S. Climate Change And Variability Trends In Pakistan And Its Environmental Effects: University of Peshawar, Peshawar; 2011. 